\title{
Front Matter: Volume 9497
}

, "Front Matter: Volume 9497," Proc. SPIE 9497, Mobile Multimedia/Image Processing, Security, and Applications 2015, 949701 (19 June 2015); doi: $10.1117 / 12.2199545$

SPIE Event: SPIE Sensing Technology + Applications, 2015, Baltimore, MD, United SPIE. States 


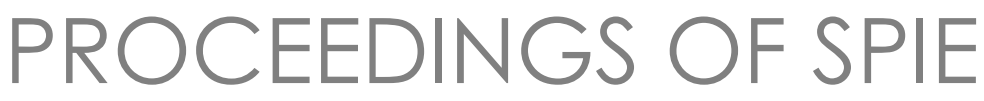

\title{
Mobile Multimedia/Image Processing, Security, and Applications 2015
}

\author{
Sos S. Agaian \\ Sabah A. Jassim \\ Eliza Yingzi Du \\ Editors
}

20-21 April 2015

Baltimore, Maryland, United States

Sponsored and Published by

SPIE 
The papers included in this volume were part of the technical conference cited on the cover and title page. Papers were selected and subject to review by the editors and conference program committee. Some conference presentations may not be available for publication. The papers published in these proceedings reflect the work and thoughts of the authors and are published herein as submitted. The publisher is not responsible for the validity of the information or for any outcomes resulting from reliance thereon.

Please use the following format to cite material from this book:

Author(s), "Title of Paper," in Mobile Multimedia/lmage Processing, Security, and Applications 2015, edited by Sos S. Agaian, Sabah A. Jassim, Eliza Yingzi Du, Proceedings of SPIE Vol. 9497 (SPIE, Bellingham, WA, 2015) Article CID Number.

ISSN: 0277-786X

ISBN: 9781628416138

Published by

SPIE

P.O. Box 10, Bellingham, Washington 98227-0010 USA

Telephone +1 3606763290 (Pacific Time) · Fax +1 3606471445

SPIE.org

Copyright @ 2015, Society of Photo-Optical Instrumentation Engineers.

Copying of material in this book for internal or personal use, or for the internal or personal use of specific clients, beyond the fair use provisions granted by the U.S. Copyright Law is authorized by SPIE subject to payment of copying fees. The Transactional Reporting Service base fee for this volume is $\$ 18.00$ per article (or portion thereof), which should be paid directly to the Copyright Clearance Center (CCC), 222 Rosewood Drive, Danvers, MA 01923. Payment may also be made electronically through CCC Online at copyright.com. Other copying for republication, resale, advertising or promotion, or any form of systematic or multiple reproduction of any material in this book is prohibited except with permission in writing from the publisher. The CCC fee code is 0277-786X/15/\$18.00.

Printed in the United States of America.

Publication of record for individual papers is online in the SPIE Digital Library.

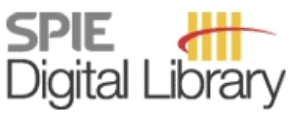

SPIEDigitalLibrary.org

Paper Numbering: Proceedings of SPIE follow an e-First publication model, with papers published first online and then in print. Papers are published as they are submitted and meet publication criteria. A unique citation identifier (CID) number is assigned to each article at the time of the first publication. Utilization of CIDs allows articles to be fully citable as soon as they are published online, and connects the same identifier to all online, print, and electronic versions of the publication. SPIE uses a six-digit CID article numbering system in which:

- The first four digits correspond to the SPIE volume number.

- The last two digits indicate publication order within the volume using a Base 36 numbering

system employing both numerals and letters. These two-number sets start with 00, 01, 02, 03, 04, $05,06,07,08,09,0 A, 0 B \ldots$. 0Z, followed by 10-1Z, 20-2Z, etc.

The CID Number appears on each page of the manuscript. The complete citation is used on the first page, and an abbreviated version on subsequent pages. 


\title{
Contents
}

\author{
$\checkmark$ Authors \\ vii Conference Committee
}

\section{SESSION 1 INNOVATIVE IMAGE PROCESSING TECHNIQUES}

949702 Color image retrieval and analysis using image color measures [9497-2]

949703 A nonparametric hypothesis testing approach to wavelet domain image fusion [9497-3]

$949704 \quad$ Improved patch-based learning for image deblurring [9497-4]

949705 Intensity and resolution enhancement of local regions for object detection and tracking in wide area surveillance [9497-5]

949706 Image restoration using 2D autoregressive texture model and structure curve construction [9497-6]

949707 European activities in civil applications of drones: an overview of remotely piloted aircraft systems (RPAS) (Invited Paper) [9497-8]

949708 3D cluster-driven trilateral filter for speckle reduction in ultrasound images [9497-10]

949709 Image enhancement using hierarchical Bayesian image expansion super resolution [9497-11]

\section{SESSION 2 SECURITY AND PRIVACY}

9497 OA Encryption for confidentiality of the network and influence of this to the quality of streaming video through network [9497-12]

9497 OB On a simulation study of cyber attacks on vehicle-to-infrastructure communication (V2I) in Intelligent Transportation System (ITS) [9497-14]

9497 OC Transform domain steganography with blind source separation [9497-15]

9497 OD Information security trades in tactical wireless networks [9497-16]

9497 OE A better detection of 2LSB steganography via standard deviation of the extended pairs of values [9497-37]

9497 OG Capon-based single-snapshot DOA estimation in monostatic MIMO radar [9497-17] 
9497 OI Experimental studies of high-accuracy RFID localization with channel impairments [9497-19]

9497 0J Efficient target tracking with an ad-hoc network of omni-directional sensors [9497-20]

\section{SESSION 4 IMPLEMENTATION AND APPLICATIONS}

9497 OK High-resolution frequency estimation using generalized coprime sampling [9497-21]

9497 OL On an investigation into Intelligent Transportation System (ITS) safety and traffic efficiency applications [9497-22]

9497 ON Emotion recognition from speech: tools and challenges [9497-40]

949700 On the universe's cybernetics duality behavior [9497-34]

\section{SESSION 5 MODULATION AND CHANNEL ESTIMATION}

9497 OP Implementing MANETS in Android based environment using Wi-Fi direct [9497-39]

9497 OQ Evaluating CMA equalization of SOQPSK-TG data for aeronautical telemetry [9497-23]

9497 OR New cognitive detection techniques for multimedia signals [9497-36]

\section{INTERACTIVE POSTER SESSION}

9497 ОT Investigation of methods to search for the boundaries on the image and their use on lung hardware of methods finding saliency map [9497-9]

9497 OU Image encryption by redirection and cyclical shift [9497-13]

9497 OV Simulating the performance of switched diversity with post-examining selection [9497-27]

9497 OW Parsimonious sidelobe control for transmit beamforming using multidimensional arrays [9497-28]

$94970 X \quad$ Fast Fourier transform-based Retinex and alpha-rooting color image enhancement [9497-29]

9497 OY Inpainting for videos with dynamic objects using texture and structure reconstruction [9497-30]

$94970 Z$ Assessment of heart rate variability based on mobile device for planning physical activity [9497-31] 


\section{Authors}

Numbers in the index correspond to the last two digits of the six-digit citation identifier (CID) article numbering system used in Proceedings of SPIE. The first four digits reflect the volume number. Base 36 numbering is employed for the last two digits and indicates the order of articles within the volume. Numbers start with 00, 01, 02, 03, 04, 05, 06, 07, 08, 09, 0A, 0B...0Z, followed by 10-1Z, 20-2Z, etc.

Agaian, Sos S., 02, 06, 0U, OX

Ahmad, Fauzia, OG, OW

Al-Talabani, Abdulbasit, ON

Alvermann, John A., OD

Amin, Moeness G., OG, OK, OW

Arigela, Saibabu, 05

Asari, Vijayan K., 05

Aspiras, Theus, 05

Atanassov, Kalin, OJ

Aziz, Benjamin, OE

Babar, Mohammad Inayatullah Khan, OP

Chakravarty, Sumit, OR

Cole-Rhodes, Arlene, $\mathrm{OQ}$

Creutzburg, Reiner, 07

DelMarco, Stephen, 03

Dong, Bo, 04

Egiazarian, K., 06

Ekedebe, Nnanna, OB, OL

Epishina, E. V., OZ

Fedosov, V. P., OT

Feria, Erlan Hector, 00

Frnda, J., OA

Gao, Chen, 02

Gapon, N. V., OY

Gonzales, Analysa M., OX

Grigoryan, Artyom M., OU, OX

Hassanien, Aboulnasr, 0G, OW

$\mathrm{Hu}$, Zilong, 08

Jakovlev, Sergej, OA

Jassim, Sabah A., ON

Jiang, Zhiguo, 04

Jouny, Ismail, OC

Khalind, Omed, OE

KoneDossongui, Serge, $O Q$

Krieger, Evan, 05

Kurdziel, Michael T., OD

Lu, Chao, OB

Marchuk, V. I., 06, OT, OY

Marsh, Ronald, 09

Maslennikov, S., OY

Mikulec, M., OA

Nabilskaya, N. V., OZ

Panetta, Karen, 02

Pauls, Eric, 01

Petrosov, S. P., 06

Qin, Si, OK

Rice, Michael, $0 Q$

Ruslyakov, D. V., OT

Sellahewa, Harin, ON
Semenishchev, E. A., OT, OZ

Sevcik, L., OA

Solodova, E. N., $\mathrm{OZ}$

Song, Houbing, $O B$

Stradanchenko, S. G., OT, OY

Straub, Jeremy, 09

Sun, Yixuan, OR

Svirin, I. S., 06, OZ

Tang, Jinshan, 08

Toral-Cruz, Homer, OA

Uhrin, D., OA

Umuolo, Henry, $0 Q$

Voronin, V. V., 06, OY, OZ

Voznak, M., OA

Waqas, Muhammad, OP

Whitney, Timothy, 09

Wiatrek, Bryan A., OU

Wright, Richard J., II, OV

Yu, Wei, OB

Zafar, Mohammad Haseeb, OP

Zhang, Haopeng, 04

Zhang, Yimin D., OG, Ol, OK, OW

Zhuravlev, A. V., OY 
Proc. of SPIE Vol. $9497949701-6$

Downloaded From: https://www.spiedigitallibrary.org/conference-proceedings-of-spie on 26 Apr 2023 Terms of Use: https://www.spiedigitallibrary.org/terms-of-use 


\title{
Conference Committee
}

\author{
Symposium Chair
}

Wolfgang Schade, Clausthal University of Technology and Fraunhofer Heinrich-Hertz Institute (Germany)

Symposium Co-Chair

Ming C. Wu, University of California, Berkeley (United States)

Conference Chairs

Sos S. Agaian, The University of Texas at San Antonio (United States) Sabah A. Jassim, The University of Buckingham (United Kingdom)

Eliza Yingzi Du, Qualcomm Inc. (United States)

Conference Program Committee

David Akopian, The University of Texas at San Antonio (United States) Salim Alsharif, University of South Alabama (United States)

Vijayan K. Asari, University of Dayton (United States)

Cesar Bandera, BanDeMar Networks (United States)

Chang Wen Chen, University at Buffalo (United States)

Reiner Creutzburg, Fachhochschule Brandenburg (Germany)

Stephen P. DelMarco, BAE Systems (United States)

Frederic Dufaux, Telecom ParisTech (France)

Touradj Ebrahimi, Ecole Polytechnique Fédérale de Lausanne (Switzerland)

Erlan H. Feria, College of Staten Island (United States)

Phalguni Gupta, Indian Institute of Technology Kanpur (India)

Yo-Ping Huang, National Taipei University of Technology (Taiwan)

Jacques Koreman, Norwegian University of Science and Technology (Norway)

Maryline Maknavicius, TELECOM \& Management SudParis (France)

Alessandro Neri, Università degli Studi di Roma Tre (Italy)

Cheryl L. Resch, Johns Hopkins University Applied Physics Laboratory (United States)

Haleh Safavi, NASA Goddard Space Flight Center (United States)

Harin Sellahewa, The University of Buckingham (United Kingdom)

Yuri Shukuryan, National Academy of Sciences of Armenia (Armenia)

Viacheslav Voronin, Don State Technical University

(Russian Federation)

Yue Wu, Tufts University (United States)

Yicong Zhou, University of Macau (Macao, China) 


\section{Session Chairs}

1 Innovative Image Processing Techniques

Sos S. Agaian, The University of Texas at San Antonio (United States) Stephen P. DelMarco, BAE Systems (United States)

2 Security and Privacy

Sabah A. Jassim, The University of Buckingham (United Kingdom)

3 Detection and Localization

Jinshan Tang, Michigan Technological University (United States)

4 Implementation and Applications

Sos S. Agaian, The University of Texas at San Antonio (United States)

5 Modulation and Channel Estimation

Sabah A. Jassim, The University of Buckingham (United Kingdom) 